\title{
Investigation of interleukin-1 alpha and interleukin-6 expression and interleukin-1 alpha gene polymorphism in keratocystic odontogenic tumors and ameloblastomas
}

\author{
Burcu Sengüven ${ }^{1}$, Tülin Oygür ${ }^{1}$
}

${ }^{1}$ Dds, Phd, Research Assistant, Dds, Phd, Professor, Chairman Of The Department, Gazi University, Faculty of Dentistry, Oral Pathology Department

Correspondence:

Gazi University, Faculty of Dentistry,

Oral Pathology Department,

8. cadde. 82. sokak Emek-Ankara-Turkey 06510

senguvenb@yahoo.com

Received: 15/02/2010

Accepted: 26/08/2010
Sengüven B, Oygür T. Investigation of interleukin-1 alpha and interleukin-6 expression and interleukin-1 alpha gene polymorphism in keratocystic odontogenic tumors and ameloblastomas. Med Oral Patol Oral Cir Bucal. 2011 Jul 1;16 (4):e467-72.

http://www.medicinaoral.com/medoralfree01/v16i4/medoralv16i4p467.pdf

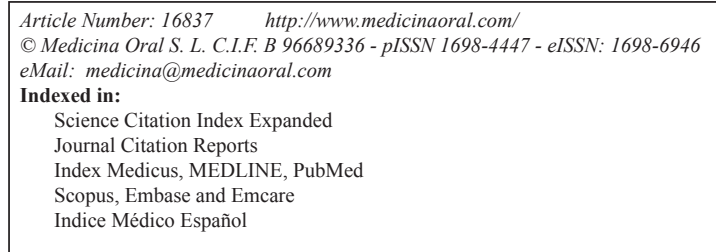

\begin{abstract}
Objective: In jawbones, ameloblastomas and odontogenic keratocysts share many clinical features in common such as aggressiveness, high recurrence rates and radical management options. Understanding the pathogenesis and biological aspects of these tumors would improve the success of diagnose and treatment procedures. The aim of this study was to exhibit the reasons of high recurrence rates and growth potentials of ameloblastomas and keratocystic odontogenic tumours by investigating the expression of IL- $1 \alpha$ and IL- 6 and IL- $1 \alpha-889$ gene polymorphism. IL-1 $\alpha$ and IL- 6 are shown as very effective tissue degrading factors in bone remodelling.

Study Design: This study included 25 cases of ameloblastomas, 41 cases of keratocystic odontogenic tumors (parakeratinized odontogenic keratocysts) and 8 cases of orthokeratinized odontogenic keratocysts. All histological slides were stained immunohistochemically to show the expression of IL-1 $\alpha$ and IL- 6 . Restriction fragment length analysis was used to investigate the cytokine gene polymorphism.

Results and Conclusions: The higher expression rates of IL-1 $\alpha$ and IL- 6 were associated with tumor size in ameloblastomas and with cyst wall thickness in keratocystic odontogenic tumors. This finding suggested us that the cytokines IL-1 $\alpha$ and IL- 6 play a role on aggressive behaviour of ameloblastomas and keratocystic odontogenic tumors by making easy bone resorption. In addition, IL-1 $\alpha$ (-889) T polymorphism was found consistent with increased IL-1 $\alpha$ expression but not seem as a risk factor on the development of these tumors.
\end{abstract}

Key words: Ameloblastoma, odontogenic keratocyst, keratocystic odontogenic tumor, interleukin, single nucleotide polymorphism. 


\section{Introduction}

Understanding the pathogenesis and biological behavior of odontogenic cysts and tumors would improve our success at diagnosis and treatment. Ameloblastomas and odontogenic keratocysts share many clinical features in common such as local aggressiveness, high recurrence rates and radical management options (1).

Ameloblastomas are the most common odontogenic tumors characterized by its histological resemblance to the enamel organ (2-5). Partial maxillectomy or mandibulectomy is the most common treatment choice with safety margin of healthy bone to avoid recurrence (6). World Health Organization (WHO) working group recommends the term of keratocystic odontogenic tumor which stresses the neoplastic nature of the entity instead of odontogenic keratocyst for parakeratinized variants $(5,7,8)$. A more "innocent" entity ortokeratinized odontogenic keratocyst (OKK) is not included in this novel classification, is still classified in developmental odontogenic cysts $(5,9)$.

Keratocystic odontogenic tumor (KOT) has an aggressive growth potential and a tendency to recur. KOTs have a thin fibrous capsule with a lining of parakeratinized squamous epithelium which has a high mitotic activity $(9,10)$.

Inflammatory cytokins such as interleukin 1 (IL-1), interleukin 6 (IL-6) and tumor necrosis factor (TNF) play important roles in bone resorption by inducing the production of matrix metalloproteinase like degradative enzymes and prostaglandins and/or differentiation and activation of osteoclast-like cells (11-13). The gene encoding IL-1 $\alpha$ is found on chromosome $2 q 13-21$ and there is a single nucleotide polymorphism at position -889. IL-1 $\alpha-889$ C/T polymorphism has been reported to be associated with an increased cytokine production (14-16). Cytokine levels, especially osteolytic cytokines found in intracystic fluids of cysts or expressed by the cells may play an important role on growth of ameloblastomas and keratocystic odontogenic tumors in jaws $(1,17,18)$.

In this research, we studied the expression of IL-1 $\alpha$ and IL- 6 by immunohistochemistry in ameloblastomas, KOTs and keratocystic odontogenic cysts with the theory of high expression of these cytokines may be a cause of reaching large sizes by bone destruction. Also we aimed to examine the influence of IL- $1 \alpha-889$ polymorphism on tumor size or recurrence because of its effect on IL-1 $\alpha$ protein expression.

\section{Material and Method}

Twenty-five ameloblastomas, 41 KOTs and 8 OKKs were selected from the archive of Gazi University Dental Faculty Oral Pathology Department. Fifteen dental follicles and 15 dentigerous cysts used as control tissues. Tumor and cyst sizes that noted during macro- scopical examination were reviewed and graded as follows: Maximum diameter between 0.5-1.9 cm: grade 1, 2.0-2.9 cm: grade 2, 3.0-3.9 cm: grade 3 and $4 \mathrm{~cm}$ and more: grade 4 .

Haematoxyline-eosin stained sections were used for grading the inflammation intensity as described before (19). Leica QWin Plus v3.3.1 (Leica Microsystems GmbH. Wetzlar, Germany) image analyze program was used to evaluate the cyst wall thicknesses of KOT and OKK.

\section{Immunohistochemistry}

The study of the expression of IL-1 $\alpha$ and IL- 6 were conducted by a technique of avidin-biotin-peroxide complex (ABC). Sections were incubated with rabbit polyclonal anti-IL-1 $\alpha$ (IL-1 $\alpha$ rabbit polyclonal antibody, cat \# ab7632, Abcam, Cambridge, UK) and goat polyclonal anti-IL-6 (IL-6 goat polyclonal antibody, Lot: sc-1265, Santa Cruz Biotechnology, Inc. CA, U.S.A) antibodies overnight at $4^{\circ} \mathrm{C}$. The dilutions of antibodies were 1:25 and 1:50 in PBS, respectively. On the following day, they were incubated with biotinylated secondary antibody and $\mathrm{ABC}$ by using Zymed Histostain Plus kit (Zymed laboratories Inc., Carlsbad, CA, USA) and Santa Cruz goat $\mathrm{ABC}$ staining system (ABC kit, Lot: sc2023, Santa Cruz Biotechnology, Inc. CA, U.S.A). 3-3' diaminobenzidine tetrachloride (DAB) was added to sections and incubated for 3-5 min. Sections were counterstained with haematoxyline. Positive control tissues were tonsil for both antibodies. The red-brown cytoplasmic staining was considered as positive. The staining intensity for antibodies was regarded intense $(+++)$, moderate (++), mild (+) and negative (-) as Kubota et al. suggested (1).

Gene polymorphism

Polymorphism at position - 889 of the IL- $1 \alpha$ was analysed by PCR-restriction fragment length polymorphism.

Sections from paraffin blocks were deparaffinized with xylene and genomic DNA was isolated with a commercial DNA extraction kit (High Pure Viral Nucleic Acid Kit, Roche Diagnostics, Germany) according to the manufacturer's instruction. For IL-1A promoter genotyping DNA was amplified by polymerase chain reaction using the primers $5^{\prime}$ AAG CTT GTT CTA CCA CCT GAA CTA GGC 3'and 3' TTA CAT ATG AGC CTT CCA TG $3^{\prime}$ as forward and reverse. For each reaction $10 \mathrm{ng}$ of genomic DNA was used as template and amplified using $2 \mathrm{mM}$ of dNTPs, $100 \mathrm{pmol} / \mu \mathrm{l}$ of each primers, $1.0 \mathrm{U}$ of taq DNA polymerase with buffer containing $\mathrm{MgCl}_{2}$. The reaction incubated for $7 \mathrm{~min}$ at $95^{\circ} \mathrm{C}$, followed by 35 cycles of $1 \mathrm{~min}$ at $94^{\circ} \mathrm{C}, 1 \mathrm{~min}$ at $55^{\circ} \mathrm{C}$ and $1 \mathrm{~min}$ at $72^{\circ} \mathrm{C}$ and a final extension of $72^{\circ} \mathrm{C}$ for $5 \mathrm{~min}$. The products were digested with $1 \mathrm{U}$ per $25 \mu \mathrm{l}$ reaction of $\mathrm{NcoI}$ at $37^{\circ} \mathrm{C}$ overnight. For analysis of IL-1 $\alpha$ polymorphism, reaction products were separated by electrophoresis on $4 \%$ agarose gels containing ethidium bromide and viewed under ultraviolet transillumination. 


\section{Statistical analysis}

The statistical analyses were carried out using SPSS (Version 12.0, SPSS Inc., and Chicago, USA) software program. Bivariate analyses were used with the level of significance set at $\mathrm{P}$ value $\leq 0.05$. Univariate analysis was performed by using logistic regression analysis to identify possible predictors of ameloblastoma or keratocystic odontogenic tumor.

\section{Results}

By immunohistochemistry, expressions of IL-1 $\alpha$ and IL-6 were detected selectively in stellate reticulum-like cells in ameloblastomas but not in basal cells of tumor islands (Fig. 1) and throughout the lining epithelial cells in KOT and OKK (Fig. 2). Staining was also seen in the inflammatory cells and endothelial cells of some capillaries. Control tissues showed no or only slight staining for both cytokines neither in lining epithelium nor in connective tissue.

In the stellate reticulum-like tumor cells of ameloblastomas, staining intensity of IL-1 $\alpha$ was mostly moderate $(++)$ and intense $(+++)$ (10 of 25 specimens). In 5 cases staining density was mild; there was no case not showing IL-1 $\alpha$ expression. IL-6, on the other hand, was negative in 11 cases and mostly mild to moderate in the remaining.
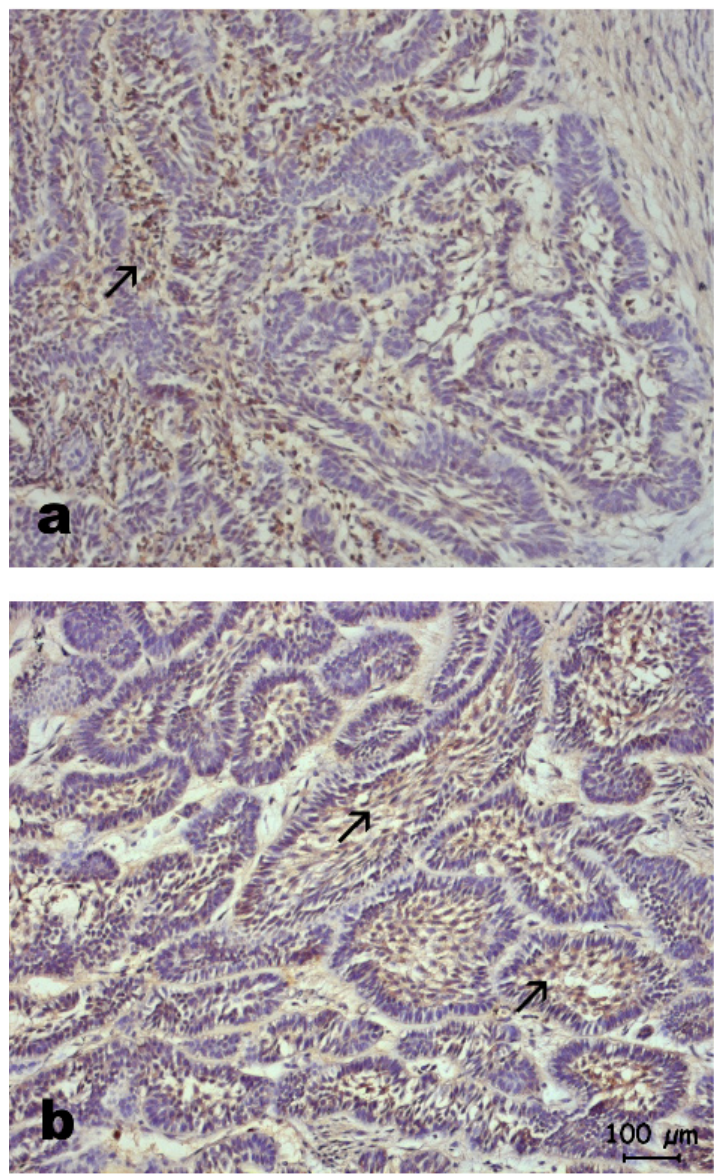

Fig. 1. IL-1 $\alpha$ (a) and IL-6 (b) expressions in stellate reticulumlike cells in ameloblastomas (a, b: x100, DAB)
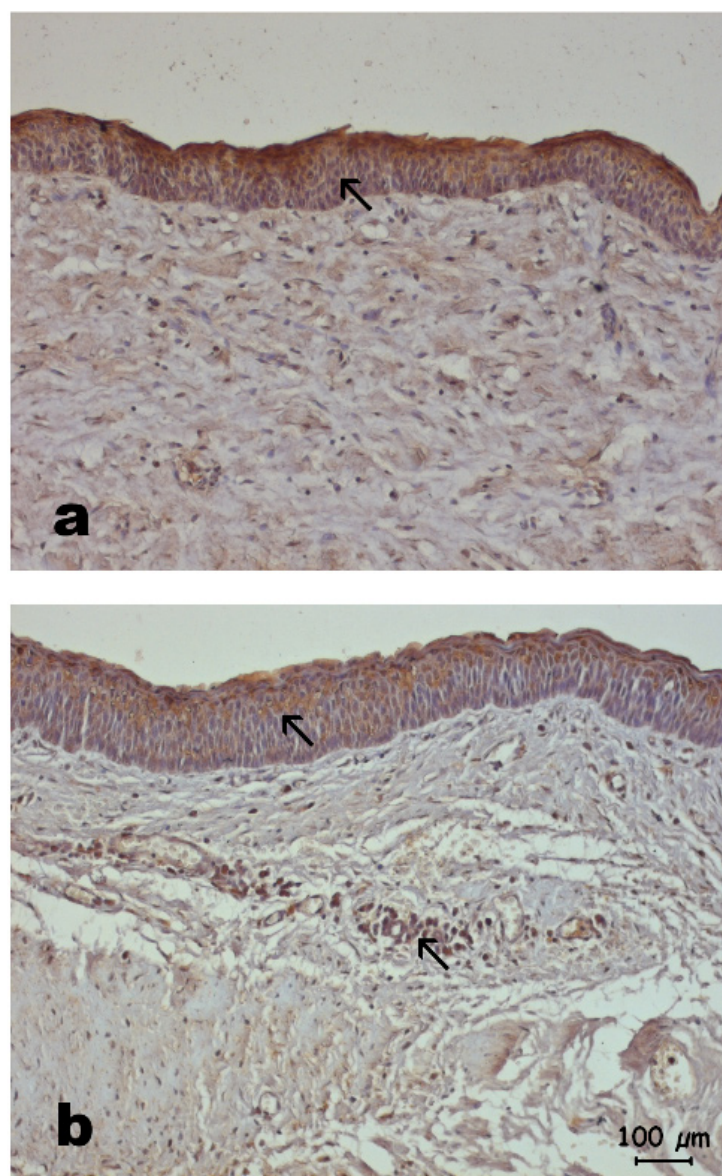

Fig. 2. IL-1 $\alpha$ (a) and IL-6 (b) expressions in lining epithelium in keratocystic odontogenic tumor and in the inflammatory and endothelial cells (a, b: x100, DAB).

In KOTs more cases showed mild staining for IL-1 $\alpha$ and moderate staining for IL-6. OKK showed nearly equal distribution in the staining density for both cytokines (Table 1).

Although the obtained values were not statistically significant, a correlation was determined between the expression of both cytokines and tumor size in ameloblastomas.

There was a correlation between the expression of IL-6 in the lining epithelium and the thicknesses of cyst wall KOTs $(\mathrm{R}=0.322, \mathrm{P}=0.020)$. The same correlation was seen between the IL-6 expression in inflammatory cells and the thickness of cyst wall $(\mathrm{R}=0.544, \mathrm{p}<0.001)$.

Expression grades of both cytokines in lining epithelium of KOTs were significantly higher than in OKK $(\mathrm{p}=0.026, \mathrm{p}=0.001)$.

The distribution of the IL-1 $\alpha-889$ genotype and allele frequencies in all cases and controls are summarized in (Table 2).

There was no significant difference between the patients with ameloblastoma, KOT and OKK or controls with respect to the genotype and allele frequencies $(p>0.05)$. 
Table 1. Immunostaining of IL-1 $\alpha$ and IL-6 in ameloblastomas, keratocystic odontogenic tumors and odontogenic keratocysts.

\begin{tabular}{|l|c|c|c|}
\hline & Immunostainings & IL-1 $\alpha$ (n) & IL-6 (n) \\
\hline \multirow{3}{*}{ Ameloblastomas $(\mathbf{n}=\mathbf{2 5})$} & - & 0 & 11 \\
& + & 5 & 7 \\
& ++ & 10 & 4 \\
& +++ & 10 & 3 \\
\hline \multirow{2}{*}{ Keratocystic odontogenic tumors } & - & 6 & 3 \\
(n=41) & + & 12 & 15 \\
& ++ & 12 & 18 \\
Odontogenic keratocycts $(\mathbf{n}=\mathbf{8})$ & +++ & 2 & 5 \\
& - & 3 & 3 \\
& ++ & 1 & 3 \\
& ++ & 2 & 0 \\
\hline
\end{tabular}

Table 2. IL-1 $\alpha-889$ allele and genotype distribution in patients and control groups.

\begin{tabular}{|c|c|c|c|c|c|c|c|c|}
\hline & \multicolumn{2}{|c|}{ Ameloblastoma } & \multicolumn{2}{c|}{$\begin{array}{c}\text { Keratocystic } \\
\text { odontogenic } \\
\text { tumor }\end{array}$} & \multicolumn{2}{c|}{$\begin{array}{c}\text { Odontogenic } \\
\text { keratocyst }\end{array}$} & \multicolumn{2}{c|}{ CONTROLS } \\
\hline Genotype & $\%$ & $\mathrm{n}(25)$ & $\%$ & $\mathrm{n}(41)$ & $\%$ & $\mathrm{n}(8)$ & $\%$ & $\mathrm{n}(30)$ \\
\hline $\mathrm{CC}(1 / 1)$ & 48 & 12 & 65.8 & 27 & 62.5 & 5 & 53.3 & 16 \\
\hline $\mathrm{CT}(1 / 2)$ & 36 & 9 & 19.5 & 8 & 37.5 & 3 & 33.3 & 10 \\
\hline $\mathrm{TT}(2 / 2)$ & 16 & 4 & 14.6 & 6 & 0 & 0 & 13.3 & 4 \\
\hline $\mathrm{Allele}$ & & & & & & & & \\
\hline $\mathrm{C}(1)$ & 66 & 33 & 75.6 & 62 & 81.25 & 13 & 64 & 42 \\
\hline $\mathrm{T}(2)$ & 34 & 17 & 24.4 & 20 & 18.75 & 3 & 36 & 18 \\
\hline
\end{tabular}

When the genetic and immunohistochemical findings compared in patients with IL-1A (CC) and (CT+TT) genotypes, increasing $\mathrm{T}$ allele frequency resulted in higher IL-1 $\alpha$ expression $(\mathrm{p}<0.001)$. Besides cases with IL-1A (CT+TT) genotypes have larger sizes than the cases with IL-1A (CC) genotype.

$\mathrm{T}$ allele carriage frequency was higher in ameloblastomas than KOT and OKK. But this finding was not statistically significant.

The allelenic frequency of IL-1 $\alpha-889$ did not deviate significantly from Hardy- Weinberg equilibrium that predicted.

\section{Discussion}

IL-1 $\alpha$ and IL- 6 are major cytokines that responsible for osteolysis (20). The osteolytic properties of IL-1 $\alpha$ and IL-6 are consistent with their possible role upon intraosseous growth and expansion of ameloblastomas and KOT $(1,18)$.
We demonstrated that IL-1 $\alpha$ and IL- 6 is expressed in stellate reticulum-like cells in ameloblastomas as Pripatnanont et al. (17) showed before. Also gave evidence of the source of IL-1 $\alpha$ in ameloblastomas by cytokine mRNA hybridization (17). As an advantage of immunohistochemistry, we showed the source of IL-1 $\alpha$ and IL-6 in ameloblastomas is stellate reticulum-like cells. IL-1 $\alpha$ protein has been shown in epithelial stellate reticulum cells in teeth germs in rats indicating that these cells are the main sources for IL-1 $\alpha$ secretion (21). As it is known, the tooth eruption is a complicated process that occurs between dental follicle and alveolar bone and requires osteoclastic activity $(22,23)$. IL- $1 \alpha$ which is synthesized by unerupted teeth germs is the principal cytokine that responsible for differentiation and activation of monocytes to osteoclasts (22). Therefore, IL-1 $\alpha$ may play important role in teeth eruption.

We found a positive relationship between increased IL-1 $\alpha$ and IL- 6 expressions and tumor size in group of 
ameloblastomas. So, it is not hard to say that IL-1 $\alpha$ and IL-6 should play important role in tumor expansion in jawbones by mediating bone lyses, exactly like materialize in teeth eruption. Kubota et al. (1) showed strong relationship between cytokine expression and matrix metalloproteinase (MMP) -2 and MMP-9 production in ameloblastomas that refers the role of cytokin and enzimatic activity in tumor spreading within the bone trabeculas. These cytokines may cause bone resorption by either stimulate differentiation and activation of osteoclasts or regulate production and secretion of degrading enzymes like MMPs $(11,24)$. Since this information is very difficult to obtain, we do not know the growing time of tumors. Proliferation potentials and possible growing times of tumors in further investigations could be very valuable for sure.

Our study showed that expressions of IL-1 $\alpha$ and IL-6 were in lining epithelial cells of KOTs and OKK as Pripatnanont et al. (17) and Ninomiya et al. (18) showed before. We also observed that staining intensities of IL$1 \alpha$ and IL- 6 in the lining epithelium of KOT and OKK were stronger than endothelial cells and fibroblasts in the connective tissue of these lesions. We suggested that growth potential of the cysts -or cystic tumors- in the jawbones is principally directed by the properties of the lining epithelial cells. Epithelial proliferation is efficient in KOT growth rather than osmotic pressure. Multicentric pattern, semi-solid areas and keep growing if not treated support this idea $(5,9)$. Like most of other cytokines IL-1 $\alpha$ and IL- 6 play role in epithelial cells as growth factor $(11,12)$. It can be proved by showing IL$1 \alpha$ and IL-6 expressions with proliferation markers like PCNA or Ki67 at the same time.

There was statistically significant relationship between IL-6 expression and connective tissue thickness in KOT and OKK. Increased IL-6 expression in lining epithelial cells and inflammatory cells is thought to play a role in fibroblast proliferation as a growth factor and/or production of extracellular matrix components from fibroblasts. Expression of IL-1 $\alpha$ and IL- 6 in KOT was significantly higher than in OKK. Although there were no statistically significant differences between two groups for age, gender, cyst wall thickness or lesion size, the different levels in IL-1 $\alpha$ and IL-6 expressions should be considered important. Positive relationship between lesion size and cytokine expression was striking only in KOTs in which recurrences and multiplicity was observed. Based on this finding it can be concluded that IL- $1 \alpha$ and IL-6 proteins play important role on the aggressive behavior of KOT in jawbones. Expressions of both cytokines in control tissues were significantly lower than in ameloblastomas, KOTs, and OKKs. Dentigerous cysts and dental follicles rarely reach significant sizes in jaw bones unlike ameloblastomas and KOTs. Weak expression of IL- $1 \alpha$ and IL- 6 could be an additional reason.
IL-1 gene, located on chromosome 2q13-21, encodes pro-inflammatory cytokine (14). Several IL-1 gene polymorphisms have been described and reported associations with inflammatory disease $(15,25,26)$. In the present study we studied the biallenic polymorphism at position IL-1 $\alpha-889$ representing a $\mathrm{C} / \mathrm{T}$ single-nucleotide polymorphism.

Our study was the first to analyze the polymorphism in the IL-1 $\alpha(-889)$ gene in ameloblastomas, KOT and OKK. There was no statistically significant difference between the lesional and control (dentigerous cysts and dental follicles) tissues on the frequencies of alleles and genotypes (Table 2). Number of the cases, although not high, was enough to say that IL- $1 \alpha-889$ polymorphism does not indicate a risk of forming ameloblastoma, KOT or OKK. The very high values we observed also supported the strong evidence of lack of correlation, despite our limited samples.

According to immunnohistochemical outcomes, increasing $\mathrm{T}$ allele frequency resulted in higher IL-1 $\alpha$ expression. Although statistical difference was not reached, our data pointed out a relationship of $\mathrm{T}$ allele frequency and tumor size. Recent studies showed that IL-1 $\alpha-889$ polymorphism increases the secretion of IL$1 \alpha(15,27)$.

The prevalence of $\mathrm{T}$ allele was higher in ameloblastomas, comparing with both KOT and OKK. There is no doubt ameloblastoma is a true neoplasia. Indeed, recent studies highlighted the role of IL-1 $\alpha$ in the development of tumors in several cancers (28). Polymorphism in this specific cytokines affects the activity and the amount of protein, gene transcriptions and the stability of mRNA (16). Therefore, IL-1 $\alpha$ gene polymorphism is thought to play a role in tumor development.

As a result, IL-1 $\alpha-889$ polymorphism is not a candidate gene alone in disease predisposition but plays an important role in progression, particularly on tumor size. On the other hand, examining the other genetic loci regulating IL-1 $\alpha$ synthesis in IL-1 gene family may be important. Accumulated effects of many polymorphisms and/ or their interactions with each other are more possible to be determinant on phenotypic features of diseases.

Showing the relationship between any single nucleotide polymorphism and tumor development and prognosis requires a long-term approach because of many other parameters and mechanisms also involve in this complicated process.

\section{References}

References with links to Crossref - DOI

1. Kubota Y, Nitta S, Oka S, Nakagawa S, Ninomiya T, Shirasuna K. Discrimination of ameloblastomas from odontogenic keratocysts by cytokine levels and gelatinase species of the intracystic fluids. J Oral Pathol Med. 2001;30:421-7.

2. Adebiyi KE, Ugboko VI, Omoniyi-Esan GO, Ndukwe KC, Oginni FO. Clinicopathological analysis of histological variants of ameloblastoma in a suburban Nigerian population. Head Face Med. 2006;2:42. 
3. Regezi JA. Odontogenic cysts, odontogenic tumors, fibroosseous, and giant cell lesions of the jaws. Mod Pathol. 2002;15:331-41.

4. Pinheiro JJ, Freitas VM, Moretti AI, Jorge AG, Jaeger RG. Local invasiveness of ameloblastoma. Role played by matrix metalloproteinases and proliferative activity. Histopathology. 2004;45:65-72.

5. Philipsen HP, Reichart PA. Revision of the 1992-edition of the WHO histological typing of odontogenic tumours. A suggestion. J Oral Pathol Med. 2002;31:253-8.

6. Sachs SA. Surgical excision with peripheral ostectomy: A definitive, yet conservative, approach to the surgical management of ameloblastoma. J Oral Maxillofac Surg. 2006;64:476-83.

7. De Vicente JC, Torre-Iturraspe A, Gutiérrez AM, LequericaFernández P. Immunohistochemical comparative study of the odontogenic keratocysts and other odontogenic lesions. Med Oral Patol Oral Cir Bucal. 2010;15:e709-15.

8. Reichart PA, Philipsen HP, Sciubba JJ. The new classification of Head and Neck Tumours (WHO)-any changes? Oral Oncol. 2006:42:757-8.

9. Mendes RA, Carvalho JF, Van der Waal I. Characterization and management of the keratocystic odontogenic tumor in relation to its histopathological and biological features. Oral Oncol. 2010;46:21925.

10. Ohki K, Kumamoto H, Ichinohasama R, Sato T, Takahashi N, Ooya K. PTC gene mutations and expression of SHH, PTC, SMO, and GLI-1 in odontogenic keratocysts. Int J Oral Maxillofac Surg. 2004;33:584-92.

11. Strand V, Kavanaugh AF. The role of interleukin-1 in bone resorption in rheumatoid arthritis. Rheumatology (Oxford). 2004;43 Suppl 3:10-16.

12. Kudo O, Sabokbar A, Pocock A, Itonaga I, Fujikawa Y, Athanasou NA. Interleukin-6 and interleukin-11 support human osteoclast formation by a RANKL-independent mechanism. Bone. 2003;32:1-7.

13. Tamura T, Udagawa N, Takahashi N, Miyaura C, Tanaka S, Yamada Y, et al. Soluble interleukin-6 receptor triggers osteoclast formation by interleukin 6. Proc Natl Acad Sci U S A. 1993;90:11924-8.

14. Coskun M, Bacanli A, Sallakci N, Alpsoy E, Yavuzer U, Yegin O. Specific interleukin-1 gene polymorphisms in Turkish patients with Behçet's disease. Exp Dermatol. 2005;14:124-9.

15. Hutyrová B, Lukác J, Bosák V, Buc M, Du Bois R, Petrek M. Interleukin 1alpha

single-nucleotide polymorphism associated with systemic sclerosis. J Rheumatol. 2004;31:81-4.

16. Ioana Braicu E, Mustea A, Toliat MR, Pirvulescu C, Könsgen D, Sun P, et al. Polymorphism of IL-1alpha, IL-1beta and IL-10 in patients with advanced ovarian cancer: results of a prospective study with 147 patients. Gynecol Oncol. 2007;104:680-5.

17. Pripatnanont P, Song Y, Harris M, Meghji S. In situ hybridisation and immunocytochemical localisation of osteolytic cytokines and adhesion molecules in ameloblastomas. J Oral Pathol Med. 1998;27:496-500.

18. Ninomiya T, Kubota Y, Koji T, Shirasuna K. Marsupialization inhibits interleukin-1alpha expression and epithelial cell proliferation in odontogenic keratocysts. J Oral Pathol Med. 2002;31:526-33.

19. Hirshberg A, Lib M, Kozlovsky A, Kaplan I. The influence of inflammation on the polarization colors of collagen fibers in the wall of odontogenic keratocyst. Oral Oncol. 2007;43:278-82.

20. Holt G, Murnaghan C, Reilly J, Meek RM. The biology of aseptic osteolysis. Clin Orthop Relat Res. 2007;460:240-52.

21. Wise GE, Lin F, Zhao L. Immunolocalization of interleukin-1 alpha in rat mandibular molars and its enhancement after in vivo injection of epidermal growth factor. Cell Tissue Res. 1995;280:21-6.

22. Marks SC Jr, Gorski JP, Wise GE. The mechanisms and mediators of tooth eruption--models for developmental biologists. Int $\mathrm{J}$ Dev Biol. 1995;39:223-30.

23. Que BG, Lumpkin SJ, Wise GE. Implications for tooth eruption of the effect of interleukin-1alpha on nuclear factor-kappaB gene expression in the rat dental follicle. Arch Oral Biol. 1999;44:961-7.

24. Kitazawa R, Kimble RB, Vannice JL, Kung VT, Pacifici R. Interleukin-1 receptor antagonist and tumor necrosis factor binding protein decrease osteoclast formation and bone resorption in ovariectomized mice. J Clin Invest. 1994;94:2397-406.

25. Hunt PJ, Marshall SE, Weetman AP, Bell JI, Wass JA, Welsh KI. Cytokine gene polymorphisms in autoimmune thyroid disease. $\mathrm{J}$ Clin Endocrinol Metab. 2000;85:1984-8.

26. Taylor JJ, Preshaw PM, Donaldson PT. Cytokine gene polymorphism and immunoregulation in periodontal disease. Periodontol 2000. 2004;35:158-82

27. Shirodaria S, Smith J, McKay IJ, Kennett CN, Hughes FJ. Polymorphisms in the IL-1A gene are correlated with levels of interleukin-1alpha protein in gingival crevicular fluid of teeth with severe periodontal disease. J Dent Res. 2000;79:1864-9.

28. Apte RN, Dotan S, Elkabets M, White MR, Reich E, Carmi Y, et al. The involvement of IL-1 in tumorigenesis, tumor invasiveness, metastasis and tumor-host interactions. Cancer Metastasis Rev. 2006;25:387-408. 